\title{
DETERMINATION OF THE RELATIONSHIP BETWEEN EGG DROP SYNDROME (EDS) IMMUNE STATUS IN VACCINATED HENS AND THEIR EGG QUALITY
}

\author{
NADIA M. IBRAHIM AND M.H. KHODEIR
}

Veterinary Serum and Vaccine Research Institute,ARC,Minstery of Agriculture ,DokkiGiza - Egypt

(Manuscript received 26 January 2011)

\begin{abstract}
The present work was carried out in a trial to overcome the possible obstacles which may face the evaluation of egg drop syndrome (EDS) vaccine through the application of the challenge test using the virulent virus. It spots the light on the relationship between the levels of EDS antibodies in vaccinated hens and the quality and quantity of laid eggs from these hens. Live attenuated chicken embryo fibroblast cell culture (CEF) and inactivated duck egg EDS vaccines were used to such purpose where they were used to vaccinate 2 groups of hens at 4 and 16 weeks of age. The induced antibodies in vaccinated hens were followed up using hemagglutination inhibition test $(\mathrm{HI})$ and serum neutralization test (SNT) revealing that all vaccinated hens exhibited high levels of specific EDS antibodies confirming the production of good quality and quantity of eggs.
\end{abstract}

\section{INTRODUCTION}

Egg drop syndrome virus (EDS) is an adenovirus (Baxendale, 1978) affecting egg production and quality in laying hens through virus replication in the uterus and lower regions of the oviduct. The virus is transmitted vertically, and the appearance of the disease around the peak of egg production may be due to reactivation of latent virus (Mcferran, 1979). Other signs of EDS infection may be recorded as inappetence and transient diarrhoea which is probably due to the exudates from the oviduct (Smyth et al., 1988).

The syndrome was recorded in Egypt for the first time by Khafagy and Hamouda (1991) through the detection of HI antibodies against EDS-76 in commercial chicken layers, while, the causing agent was isolated by Ahmed (1995).

It was noticed that both normal and abnormal shelled eggs produced during the period of virus replication in the pouch shell gland contained virus on the exterior and anterior leading to contamination of egg trays (Cook and Darbyshire, 1980) and the presence of the virus in the feces arises from contamination by oviduct exudates (Smyth et al., 1988).

When vertical or lateral transmission of EDSV occurs, the flocks should be protected by vaccination in growing period. Birds would be vaccinated between 14 and 
16 weeks of age, exhibiting immunity lasts at least one year (Solyom et al., 1982). It was concluded that the inactivated vaccine is effective in the control of EDS-76 infection.

It was established that, challenge of vaccinated chickens against the virulent agent of the used vaccine is an essential step in the quality control of the tested vaccine, but, this step may lead to spread infection to other flocks under unrestricted hygienic measures or even with the carelessness of workers, in addition to the high cost of such test.

The present work tries to determine the relationship between the EDS antibody titer in vaccinated hens and the quality of their eggs to avoid any possible risks.

\section{MATERIALS AND METHODS}

\section{Vaccines}

Lyophilized EDS-76 live attenuated vaccine prepared on CEF cells was prepared locally in Veterinary Serum and Vaccine Research Institute with a titer of 12 $\log _{10}$ TCID $_{50} / \mathrm{ml}$ (Nadia and Abo zaid 2010).

Inactivated oil emulsion EDS-76 vaccine prepared on duck eggs was locally prepared in the same institute.

Attenuated EDS76 virus: EDS-76 virus adapted on chicken embryo fibroblast (CEF) cell culture (Nancy et al., 2003) was used for serum neutralization test.

Chicken embryo fibroblast cell culture (CEF): Primary CEF cell culture was prepared according to Singh et al . (1967) and used in serum neutralization test for estimation of EDS serum neutralizing antibodies.

Three hundreds one day old Hubbard chicks were obtained from the United Company for Poultry Production. These chicks were divided into 3 groups each of 100 birds reared under hygienic measures where the first group was vaccinated with 2 doses of the live attenuated vaccine prepared on CEF cell cultures at the $4^{\text {th }}$ and $16^{\text {th }}$ week of age, respectively. The second group was vaccinated with the duck egg inactivated vaccine at the same periods, while, the third group was kept as nonvaccinated control.

Each bird in the groups vaccinated with the live EDS 76 vaccine was installed intra-ocular with a dose containing at least $10^{6} \mathrm{TCID}_{50}$, whereas chickens vaccinated with the inactivated EDS76 vaccines received a dose of $0.5 \mathrm{ml} /$ bird inoculated I/M. Twenty random serum samples were obtained from each chicken 
group weekly up to the first 4 weeks, then every 4 weeks (monthly) up to 16 weeks of age (the time of the second vaccination), and then, weekly up to 20 weeks of age (4 weeks post the second vaccination), and then, monthly up to 8 months of age (32 weeks post- the last vaccination).

Serum neutralization test (SNT): It was performed as described by Roositer et al . ( 1985) and the antibody titer was calculated as the reciprocal of the final serum dilution which neutralized and inhibited the CPE of $100 \mathrm{TCID}_{50}$ of EDS virus according to Singh et al. (1967).

Haemagglutination inhibition test (HI): It was carried out according to Anon (1971).

Egg curve: It was drawn to evaluate the quantity and quality of eggs produced by vaccinated chickens.

\section{RESULTS}

Table 1. Mean titers of serum neutralizing EDS antibodies in vaccinated chickens.

\begin{tabular}{|c|c|c|c|c|c|c|c|c|c|c|c|c|c|}
\hline \multirow{2}{*}{$\begin{array}{c}\text { Used } \\
\text { vaccine }\end{array}$} & \multicolumn{13}{|c|}{ Mean EDS serum neutralizing antibody titer } \\
\hline & $\begin{array}{l}\uparrow \\
4\end{array}$ & $\begin{array}{c}5 \\
\text { WA }\end{array}$ & $\begin{array}{c}6 \\
\text { WA }\end{array}$ & $\begin{array}{c}7 \\
\text { WA }\end{array}$ & $\begin{array}{c}8 \\
\text { WA }\end{array}$ & $\begin{array}{c}\uparrow \\
16\end{array}$ & $\begin{array}{c}17 \\
\text { WA }\end{array}$ & $\begin{array}{c}18 \\
\text { WA }\end{array}$ & $\begin{array}{c}19 \\
\text { WA }\end{array}$ & $\begin{array}{r}20 \\
\text { WA }\end{array}$ & $\begin{array}{c}24 \\
\text { WA }\end{array}$ & $\begin{array}{c}28 \\
\text { WA }\end{array}$ & $\begin{array}{c}32 \\
W A\end{array}$ \\
\hline Live & WA & & & & & WA & & & & & & & \\
\hline CEF & $\begin{array}{c}* \\
\left(1^{\text {st }}\right.\end{array}$ & 8 & 16 & 24 & 32 & $\begin{array}{l}\left(2^{\text {nd }}\right. \\
\text { Vac.) }\end{array}$ & 40 & 64 & 128 & 128 & 128 & 128 & 128 \\
\hline $\begin{array}{l}\text { Inac. } \\
\text { duck }\end{array}$ & $\begin{array}{c}\text { Vac.) } \\
* *\end{array}$ & 4 & 8 & 18 & 30 & $\begin{array}{c}* * * \\
\downarrow\end{array}$ & 40 & 64 & 64 & 128 & 128 & 128 & 128 \\
\hline egg & $\downarrow$ & & & & & & & & & & & & \\
\hline $\mathrm{C}$ & & 0 & 0 & 0 & 0 & & 0 & 0 & 0 & 0 & 0 & 0 & 0 \\
\hline
\end{tabular}

$* \mathrm{WA}=$ week of age

$* * 1^{\text {st }}$ Vac. $=$ first vaccination $* * * 2^{\text {nd }}$ Vac. $=$ second vaccination.

Table 2. Mean HI titers of EDS antibodies in vaccinated chickens.

\begin{tabular}{|c|c|c|c|c|c|c|c|c|c|c|c|c|c|}
\hline \multirow{3}{*}{$\begin{array}{c}\text { Used } \\
\text { vaccine }\end{array}$} & \multicolumn{13}{|c|}{ Mean HI titers of EDS serum antibodies $(\log 2 / \mathrm{ml})$} \\
\hline & $\uparrow$ & 5 & 6 & 7 & 8 & & 17 & 18 & 19 & 20 & 24 & 28 & 32 \\
\hline & 4 & WA & WA & WA & WA & $\uparrow$ & WA & WA & WA & WA & WA & WA & WA \\
\hline Live & WA & & & & & 16 & & & & & & & \\
\hline CEF & * & 4 & 8 & 11 & 11 & WA & 12 & 12 & 13 & 11 & 12 & 12 & 12 \\
\hline Inac. & $\left(1^{\text {st }}\right.$ & & & & & $\left(2^{\text {nd }}\right.$ & & & & & & & \\
\hline duck & Vac.) & 2 & 4 & 8 & 9 & Vac.) & 11 & 12 & 13 & 12 & 11 & 13 & 12 \\
\hline egg & $* *$ & & & & & $* * *$ & & & & & & & \\
\hline C & $\downarrow$ & 0 & 0 & 0 & 0 & $\downarrow$ & 0 & 0 & 0 & 0 & 0 & 0 & 0 \\
\hline
\end{tabular}

$*$ WA $=$ week of age

$* * 1^{\text {st }}$ Vac. $=$ first vaccination

$* * * 2^{\text {nd }} V a c .=$ second vaccination 
Table 3. Mean quantities of egg production with good quality starting from 16 weeks of age.

\begin{tabular}{|c|c|c|c|c|c|c|}
\hline \multirow{2}{*}{$\begin{array}{c}\text { Used } \\
\text { vaccine }\end{array}$} & $\begin{array}{c}\text { Number of } \\
\text { hens }\end{array}$ & \multicolumn{5}{|c|}{ Mean quantities of egg production/ weeks of age } \\
\cline { 3 - 7 } & 100 & 300 & 320 & 310 & 295 & 300 \\
\hline Live CEF & 16 WA & 20 WA & 24 A & 28 WA & 32 WA \\
\hline $\begin{array}{c}\text { Inactivated } \\
\text { duck egg }\end{array}$ & 100 & 290 & 285 & 315 & 300 & 275 \\
\hline Control & 100 & 270 & 227 & 299 & 307 & 298 \\
\hline
\end{tabular}

*WA=week of age

\section{DISCUSSION}

This work has investigated the correlation between the EDS immune status in vaccinated hens and the quality and quantity of produced eggs avoiding the application of challenge test to evaluate the vaccine potency.

Maternal antibodies against EDS were screened in the experimental chickens at 4 weeks of age before vaccination, and it was found that they were free from such antibodies. All vaccinated chickens did not show any abnormal signs allover the experimental period confirming vaccine safety. SNT and HI results revealed that vaccination of chickens at 4 weeks and revaccinated at 16 weeks of age before starting of the season of egg production induced high levels of antibodies and egg production. The results of serum neutralization test (SNT) as shown in Table 1 showed the maximum value (128), and Table 2 showed the highest HI titer $(13 \log 2)$ by the $3^{\text {rd }}$ week post- the $2^{\text {nd }}$ vaccination and still high up to 32 weeks of age (16weeks postboostering), coming in agreement with what reported by Rhee et al. (1987) and Nadia (2004\&2010). These determined titers appear to be sufficient to protect hens against virus infection as stated before by Baxendale (1978) and Khodeir and Amina (1999). In addition, Khalaf et al . (1982) and Nadia (2010) recorded high protective titers of EDS antibodies between the $2^{\text {nd }}$ and $5^{\text {th }}$ week post-the $2^{\text {nd }}$ vaccination.

Also, vaccination programs in young age (4weeks) followed by another dose before the period of egg production was suggested and confirmed by Kaur et al. (1997) and Kozlina et al . (1990) providing high immunity to chicks .

On investigation of the mean quantity and quality of the egg production (Table 3) of vaccinated chicks, it was noticed that there was no abnormality in the quality of laid eggs with good level of production in comparison to the healthy unvaccinated well managed and fed hens indicating that the prepared vaccines are effective to withstand EDS76 virus infection and protect the chicks against both production drop and poor quality of eggs as recommended by Cook and DarbyShire (1980). The irregular increase and decrease in the quantity of egg production in vaccinated and unvaccinated groups appears to be within the normal status of chicks, in agreement with what mentioned by McFerran (1979), Friederichs et al. (1987) .

So, the immune status of EDS in hens can reflect the quality and quantity of egg production and vis-a -vis. 


\section{REFERENCES}

1. Ahmed, M.H.H. 1995. Viruses associated with dropping production. Ph.D Thesis, Fac. Vet. Med, Cairo University.

2. Anon, M. 1971. Method for examination of poultry biologics and identifying and quantifying avain pathogens.National Academy of science, Washington, D.S. U.S.A.

3. Baxendale, W.1978.Egg drop syndrome 76. Vet. Rec, 12:285-286.

4. Cook J.K.A. and J.H. Darbyshire. 1980. Epidemiological studies with egg drop syndrome 1976 (EDS76) Virus.Avian pathol. 17: (653-666).

5. Friederichs, m., O. Siegmann, U. Heffels Redmann, E. F. Kaleta and M. Neumann. 1987. Pathogensis of egg drop syndrome 76 after experimental infection of day old chicks and laying hens.Berliner and München Tierarztliche Wochenschrift, 100(2): 41-47.

6. Kaur,A. M.S. Obsevoi and Amarjit Singh. 1997. Neutralizing antibody and challenge response to live and inactivated avian adenovirus $-I$ in broilers.Tropic. Anim.Hlth. produc., 29(3): 141-146.

7. Khafagy, A.K. and M.S.M. Hamouda. 1991. Studies on egg drop syndrome (1976). Existance of antibodies in Egyptian commercial chicken layers.Vet. Med. J., Giza, 39(2):287-292.

8. Khalaf, S.E.D, EF. Kaleta and O. Siegmanuu. 1982. Comparative studies on the Kinetics of Hemagglutination inhibition and virus neutralizing antibodies following vaccination of chickens against egg drop syndrome 1976 (EDS76). Dev Biolstand 51: 127-137.

9. Khodeir, M.H. and Amina A. El-Bayomy. 1999. Preparation and evaluation of a combined vaccine against fowl cholera and egg dropsyndrome. Egypt. Vet. Med. Assoc., 59 (2\&3): 449-470.

10. Kozalina, Boknezevic, w., J. Wikolovski and V. Matovic. 1990. Immunoprophylaxis of poultry with inactivated vaccine in parallel study of immunogenicity of polyvirols 3 and appropriate inactivated monovalent vaccines. Acta veterinaria Beograd, 402-3:129-135.

11. Mcferran, J. B. 1979. Egg drop syndrome1976 (EDS76) Tidschr Diergeneeskd, Vet. Quart, 104(20): Supp1-4: 176-180.

12. Nadia, M. I. 2004. Preparation and evaluation of attenuated and inactivated egg drop syndrome virus vaccines adapted on chicken kidney cell culture.Egypt. vet.polul.Assoc.,6th Sci.Conf,pp.360-366. 
13. Nadia, M.I. 2010. Vaccination programs for Egg Drop syndrome (EDS) using local prepared vaccines. Egypt .J,Agric.Res, volume 88(3) 2010.

14. Nadia, M.Ibrahim and A.A. Abu zaid. 2010. Trial for propagation and adaption of EDS virus vaccine on CEF and SPF eggs .Egypt .J,Agric.Res, volume 88(3) :2010.

15. Nancy, B. Rofail, Nadia M. Ibrahim, Hala M. El-makaky and A. El-Bordiny Fekria. 2003. Trial for propagation of EDS-76 virus on different tissue culture types .Kafrel-shikh vet.med .J. (1):697-707.

16. Rhea, Y.O, J. H. Kin and S. Namgoong. 1987. Immunogenicity of ND-EDS 76-IBD Combined oil adjuvnmat vaccine Research reports of this Rural Development Administration.Live stock and veterinary 29(1): 209-212.

17. Rossiter, P.B., D. M. Tessett and W. P. Taxfor. 1985. Micro neutralization system for use with different strains of peste des petits ruminants virus and Rinder peste virus.Trop. Anim. Hlth. Prod., 17(2):75-81.

18. Singh, K. V., O.A.Osman,I.E.EL-Cicy, F. A. Ata and T. I. Baz. 1967.Response of water buffaloes to experimental injection with rinder pest virus.Cornell. Vet., 57: $638-648$

19. Smyth, J. A., M.A.Platten and J. B. Mcferran. 1988. A study of the pathogenesis of egg drop syndrome in laying hens .Avian pathol., 17(653-666).

20. Solyom, F. M. Nemesi, A. Forgacs, E. Bella and T. pereny. 1982. Studies on EDS vaccine.Dev Bid stands 1:105-121. 
تحديد العلاقة بين الحالة المناعية لظاهرة تلنى البيض فى الاجاج المحصن ونوعية البيض

نادية محمد إبر اهيم , محمد خضير

معهُ بحوث الأمصال و اللقاحات البيطرية بالعباسية - مركزالبحوث الزراعية - وزاره النرراعة الدقي- جيزه

تم إجر اء هذه الدراسة كمحاولة للتغلب على تطبيق اختبار التحدى عند تقييم فاعلية لقاح

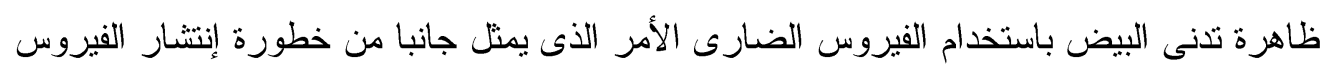

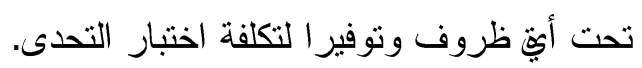

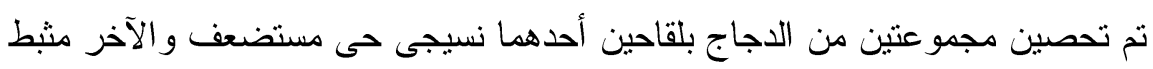
محضر فى أجنة بيض البط بتقديم جرعتين عند عمر 4 و16 أسبوع ثم تم تتبع مستويات الأجسام

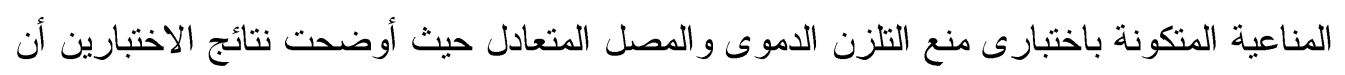
الطيور المحصنة تكتسب مستويات مناعية جيدة تكفى لحماية الدجاج ضد الفيروس الضارى مع إنتاج

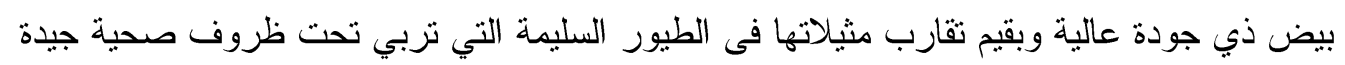

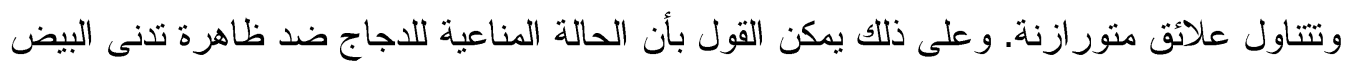
تدل على نوعية البيض الناتج من حيث الكم و الكيف. ولئ. 